\title{
Acanthospermum hispidum DC (Asteraceae): perspectives for a phytotherapeutic product
}

\author{
Evani de L. Araújo, ${ }^{*, 1}$ Karina P. Randau, ${ }^{1}$ José G. Sena-Filho, ${ }^{1}$ Rejane M. Mendonça \\ Pimentel, ${ }^{2}$ Haroudo S. Xavier ${ }^{1}$ \\ ${ }^{1}$ Laboratório de Farmacognosia, Departmento de Ciências Farmacêuticas, Universidade Federal de Pernambuco, \\ Av. Prof. Arthur de Sá s/n, Cidade Universitária, 50740-521 Recife-PE, Brazil, \\ ${ }^{2}$ Laboratório de Fitomorfologia, Departamento de Biologia, Universidade Federal Rural de Pernambuco, Av. \\ Manoel de Medeiros, s/n, Dois Irmãos, 52171-900 Recife-PE, Brazil
}

\begin{abstract}
RESUMO: “Acanthospermum hispidum DC (Asteraceae): perspectivas para um produto fitoterápico". A planta "Espinho-de-cigano" (Acanthospermum hispidum DC) é amplamente usada no nordeste do Brasil como medicamento popular para a asma. Embora muito pouco seja conhecido atualmente sobre a eficácia e segurança deste extrato vegetal, é possível encontrar numerosos medicamentos preparados com ele nos serviços públicos ou em lojas que vendem produtos naturais. Este estudo visa proceder a uma revisão de literatura relativa à $A$. hispidum, no período entre 19262006, nas áreas de etnobotânica, fitoquímica e farmacologia. O objetivo foi contribuir para um melhor conhecimento desta espécie e seus usos, assim como auxiliar na melhora de seu desempenho como um medicamento natural. A espécie é facilmente identificável e cresce abundantemente durante a estação chuvosa no nordeste do Brasil; é possível cultivá-la sem perda de seu perfil fitoquímico e os estudos toxicológicos têm mostrado sua segurança como um medicamento (embora mais estudos sejam requeridos nestes aspectos). Assim sendo, a compilação do conhecimento acumulado relativo a esta espécie auxiliará na avaliação de seu valor farmacológico, garantindo o controle de qualidade do produto final, e no preparo das recomendações para usos e dosagens que ofereçam segurança e eficiência ao usuário.
\end{abstract}

Unitermos: Acanthospermum, Asteraceae, plantas medicinais, fitoquímica, asma.

\begin{abstract}
The "Espinho-de-cigano" plant (Acanthospermum hispidum DC) is used throughout northeastern (NE) Brazil as a folk medicine for asthma. Although little is actually known about the effectiveness and safety of this plant extract product, it is possible to find numerous medicines prepared from it in public health services or in stores selling natural products. This study aimed to undertake a literature review relative to Acanthospermum hispidum covering the period between 1926-2006 within the areas of ethnobotany, phytochemistry and pharmacology. The objective was to contribute to a better knowledge of this species and its uses, as well as to aid in improving its performance as a natural medicine. The species is easily identifiable and grows abundantly during the rainy seasons in NE Brazil; is amenable to cultivation without lose of its phytochemical profile, and toxicological studies have showed its safety as a medicine (although more studies will be required in that direction). As such, the compilation of the accumulated knowledge concerning this species will aid in evaluating its pharmacological value, guaranteeing quality control of the final product, and in preparing recommendations for usages and dosages that offer both safety and efficiency to the user.
\end{abstract}

Keywords: Acanthospermum, Asteraceae, medicinal plants, phytochemistry, asthma.

\section{INTRODUCTION}

Acanthospermum hispidum, popularly known as "Espinho-de-cigano" ("Gypsy-Thorn"), has been traditionally used in northeastern Brazil for treating asthma, bronchitis, fevers and as expectorant, as vermifuge and against intestinal pains (Morais et al., 2005; Tôrres et al., 2005; Agra et al., 2007; 2008). Recent public health programs showed the results obtained in treating bronco-asthmatic problems with syrups prepared from this plant have raised awareness about this folk medicine and has provoked a significant increased in demand for this product. It is also possible to find extracts of this plant in stores specializing in natural products and natural medicines, although these preparations often do not meet even the minimal requirements the National Health Service Agency Anvisa (2000), in terms of their quality control, proof of efficiency, or safety (Araújo et al., 2002). Even recognizing the normal difficulties involved in working with folk remedies and products of extensive 
popular usage, a lack of research and control may expose patients to an inefficient use of such a product or even health risks.

It is well known that commercial marketing of any medicine extends from the initial identification of a potentially useful species through the long processes and high costs of intensive research on the quality, safety and efficiency (although this process is often more efficient when natural products are involved, in contrast to purely synthetic compounds). There has been a tendency throughout the world for increasing demands for phytotherapeutic compounds, stimulating the interest of large laboratories in finding more of these "new" drugs. But in spite of the growth of the pharmaceutical industry, significant numbers of people still depend on home remedies and self-medication, creating a need and an interest in reorganizing the cultural and scientific knowledge concerning popularly used plants - the goal of the present work.

\section{MATERIAL AND METHODS}

An extensive bibliographic search was undertaken to identify works on medicinal plants published in periodicals, data banks, and rare or current texts stored in public and private libraries during the period between 1926 and 2006, including sources such as NAPRALERT - Natural Products Alert, the data bank of the University of Illinois, Chicago; Chemical Abstracts; ICBN - International Code of Botanical Nomenclature; FDA - Food \& Drugs Administration (USA), the on-line periodical bank of the Coordination for Improvement of Graduate Level Personnel (CAPES), and similar sources. Additionally, we consulted published monographs, thesis, and proceedings of scientific congresses, websites, and technical research publications, as well as production protocols of the Laboratory of Phytotherapy of the Municipality of Olinda, Pernambuco State, Brazil where plant extracts of Acanthospermum hispidum have been produced and utilized for more than ten years as a main component of phytoterapic product.

\section{RESULTS AND DISCUSSION}

\section{Botanical investigations}

The specie name of Acanthospermum hispidum was derived from the Greek words ákanthos and sperma, which mean "thorn" and "seed", respectively (Cunha, 1982); while hispidum is derived from Latin, meaning "rough" (referring to the rough hairs covering the seed) (Saraiva, 2000). Also, the name describes a hirsute species with seeds protected by hairs and thorns.

The family Asteraceae (Dumortier 1822 nom. conserv.) is known in older texts as the Compositae. It is the largest angiosperm family (Cronquist, 1981; Barroso et al., 1991; Verdi et al., 2005), containing more than
1,500 genera comprising approximately 25,000 known species (ICBN, 2005; Verdi et al., 2005) and represents nearly $10 \%$ of the world's total flora (Bremer, 1994). Although about $98 \%$ of the Asteraceae are small plants, the family also includes subshrubs, vines, a few trees, and even some aquatic species. The principal defining characteristic of this family is the presence of numerous flowers united in a capitulum (Joly, 1978).

The genus Acanthospermum (Schrank. Pl. Rar. Hort. Monac. 53, 1819) (Aranha et al., 1972) comprises annual herbaceous plants that are either erect or prostrate. The leaves are simple, opposite, with serrate or entire margins, and the inflorescence is axial or terminal, with yellow flowers. The fruit is an achene, oblong, with rigid and persistent hairs. The principal species composing this genus are: australe (Loefl.) Kuntze, 1891; brachyceratum S.F. Blake, 1922; brasilum (Schrank, 1822); donii (S.F.) Blake, 1921; glabratum (DC.) Wild, 1967; hirsutum DC., 1836; hispidum DC., 1836; hispidum A. Chev., 1920; humile (Sw.) DC. 1836; humile var. hispidum (DC.) Kuntze, 1891; humile var. hispidum Kuntze, 1891; lecocarpoides B.L. Rob. \& Greenm., 1895; leptolobum S.F. Blake, 1922; microcarpum B.L. Rob., 1902; simile S.F. Blake, 1921; xanthioides (Kunth) DC., 1836; xanthioides var. acutifolium; xanthioides var. glabratum DC., 1836; and xanthioides var. obtusifolium DC., 1836. The species australe and hispidum have economic importance in Brazil, as they are invasive weeds in agricultural fields. They are denominated in many regions with the same popular name and are often considered to have the same medicinal uses (Lorenzi \& Matos, 2002).

Cronquist (1981) observed that phytochemical modifications may have been even more important than morphological changes in terms of the evolutionary success of this family, as exemplified by the utilization of polyacetylenes and sesquiterpenoid lactones to repel predators that have adapted to the iridoids produced by the older members of these taxa.

In the specific case of the species $A$. hispidum (DC. Prodr. 5:522, 1836) (Aranha et al., 1972), Stuessy reviewed the sub-tribe Melampodiinae, to which this species belongs, on two occasions (in 1973 and in 1977); in the second revision this author redistributed the component genera (Seaman et al., 1980). In 1979, Bohlmann proposed the use of sesquiterpene lactones as taxonomic markers in the identification of the tribe Heliantheae. As such, sesquiterpenoid-lactones have an important taxonomic role in the Asteraceae, with more than 900 of these compounds already identified, some of them showing anti-helmintic, anti-parasitic, antibiotic, and anti-carcinogenic activities (Bruneton, 1991; Evans, 1996).

The species $A$. hispidum is an erect annual plant, reaching up to one meter in height, with stems and leaves that are densely pubescent. The root system is ramified, showing a principal root up to $20 \mathrm{~cm}$ long with innumerous secondary roots, and gives off a 
characteristic light, slightly sweet, aroma. The stem is covered with fine hairs, the leaves have a bitter taste, simple and opposite, and measuring on the average $6 \mathrm{x}$ $3 \mathrm{~cm}$. The flowers are axillary, arranged in capitula, with small yellow flowers. The fruits are achenes, long, with a triangular form, and covered with irregular hairs that lend the plant other popular names, including "carrapicho-decarneiro" (sheep's-thistle) or "carrapicho-de-três-pontas" (three-pointed-thistle) (Aranha et al., 1972; Corrêa, 1926; Lorenzi, 1982; Coimbra, 1994).

\section{Geographical and agricultural profile}

Although $A$. hispidum is pantropical (Menut et al., 1995), the species is considered to have its origin in central and southern America (Braga, 1976). It occurs in Brazil from the state of Piauí south to Rio Grande do Sul (Braga, 1976; Corrêa, 1978). It was probably introduced from South America to both India (Nair et al., 1985) and Africa (Summerfield \& Saalmullera, 1998), which may be one of the sources of the large number of popular names attributed to this plant. Due to its role as an invasive weedy species on agricultural lands it has been the subject of many publications in Brazil and other countries. A. hispidum can be found in the wheat fields in the state of Minas Gerais (Cunha et al., 1985; Brandão et al., 1986a) through urban coastal areas in the municipality of Rio de Janeiro (Brandão et al., 1986b), although it is less frequent in the northern and northwestern regions of the country. It occurs spontaneously and predominantly along the coast in the state of Pernambuco, having also been detected in numerous cities in the interior of that state (Tabarelli \& Silva, 2002).

Although $A$. hispidum has long been principally considered an invasive weed of agricultural plantations, it has recently become sought after as raw material to manufacture syrup produced by public health services in a number of municipalities to treat asthma. A year-round demand for this plant has led to its cultivation, as it occurs spontaneously only during the rainy season.

Although is not very competitive when compared to other invasive weeds (Voll et al., 1997), A. hispidum has been shown to be resistant to a number of different types of herbicides (Reddy, 1965, Luo \& Matsuomoto, 2002), and has showed an insecticidal activity against the larvae of a species of lady-bug (Epilachna varivestes) (Kraus et al., 1994).

In general, the seeds of $A$. hispidum remain dormant in the soil for periods of up to eight years, reappearing at each new preparation of the soil (Schwerzel \& Thomas, 1979) according to the rainfall and temperature regime. Garcia (1992) examined seed dormancy and related it to climatic factors, noting that dormancy could be broken by incubation in the dark for 10-30 days.

Preliminary experiments undertaken by Messias \& Noronha (1994) at the Pernambuco Agricultural
Research Group (IPA) recommended fertilizing the soils used for cultivating this species with $15 \%$ urban compost, with additions of ammonia, phosphate and potassium (40-20-40).

Cultivated specimens of $A$. hispidum will germinate on a wide variety of soils, from sandy to clay. The transition from the flowering to the fruiting phase of this species is extremely rapid, demonstrating a metabolic priority of reproduction over the elaboration of chemical defenses (Miranda, 1996).

\section{Phytochemistry}

Asteraceae has been one of the most studied plant families, in large part due to the promising chemical compounds produced by this group. This research has lead to the development of pharmaceutical compounds, insecticides (such as piretro), and other products. In the specific case of $A$. hispidum, there is a huge volume of literature related to research on numerous chemical components extracted from this plant, as well as chemotaxonomic and phytotherapeutic investigations. The oldest phytochemical studies encountered dated to 1975, when Herz reported investigations concerning sesquiterpene lactones with potential biological activities, and to 1976, when Ramachandran et al., as well as Mathur \& Bejarane, published further studies on A. hispidum. The sesquiterpene lactones found in A. hispidum are chemically distinct from other sesquiterpenoids due to the presence of an $\alpha$-methylene- $\gamma$-lactone system, many containing carbonyl $\alpha, \beta$-unsaturated and epoxies, which are part of a larger family of compounds with a wide spectrum of biological activity, including anti-microbial and anti-tumor activities (Robers, 1997). Using thinlayer chromatography, Xavier \& Araújo (1998) studied samples of plants that were either cultivated or growing spontaneously, and found no qualitative differences in their phytochemical patterns. The use of these plants as forage by cattle during the dry season has drawn investigative interest because of the reported toxicity of the seeds (Cunha et al., 1985).

Investigationsofotherspecies of Acanthospermum have led to the isolation of cis-cis-germacranolides and melampolides. Additional compounds isolated from $A$. hispidum are listed in Table 1.

\section{Uses}

Many species imported by Europeans and Africans during the early colonization of Brazil became acclimatized and incorporated into the already rich plant heritage of the country. Likewise, many native plant species were carried to other regions, often in an involuntary manner. This was probably the case of Acanthospermum, whose seeds adhere to clothes or animal fur, and is now found in many different countries and even on other continents around the world. 
Table 1. Chemical compounds present in Acanthospermum hispidum.

\begin{tabular}{ll}
\hline Plant & Compounds \\
\hline Entire plant & n-butyl eicosanate, n-heptacosanol triacontane (Mathur \& Bejarane, 1976) (Nair et al., 1976). \\
Aerial part & $\begin{array}{l}\text { Sesquiterpene lactones (Bohlmann et al., 1979; Jakupovic et al., 1986, Cartagena et al., 2000) some of } \\
\text { them glycoside (acanthospermol- } \beta \text {-galactosidopyranoside) (Ramachandrana et al., 1976; Geran et al., 1972 } \\
\text { apud Jakupov et al., 1986; Herz \& Kalyanarama, 1975), besides monosaccharides, disaccharides and } \\
\text { polyols, glucose, fructose, sucrose, mannose, glucuronic acid, and mannitol (Hussain et al., 1990). } \\
\left.\text { guianolides hispidunolides A e B ( } \mathrm{C}_{22} \mathrm{H}_{28} \mathrm{O}_{8}\right) \text {, melampolide, loliolide (Cartagena et al., 2000). }\end{array}$ \\
& $\begin{array}{l}\text { Saponins (Odebiyi \& Sofowora, 1978), alkaloids (Sultanbawa et al., 1978), polyphenolic constituents } \\
\text { (flavones, caffeic acid and phenylpropans), acanthospermol galactoside (Ramachandrana et al., 1985), } \\
\text { sesquiterpene hydrocarbons, } \beta \text {-caryophyllene, } \alpha \text {-humulene, bicyclogermacrene, germacrene D, } \alpha \text {-bisabolol, } \\
\text { nonanal, carvacrol and methyl carvacrol (Menut et al., 1995). }\end{array}$ \\
& $\begin{array}{l}\text { Tridecapentaynene (Ramachandra et al., 1976), aminoacids (Araújo et al., 1989), Saponins, sugars and } \\
\text { polyphenols (catequins, coumarins, flavones), (Caetano et al., 1990), caffeic acid esters (Xavier \& Araújo, } \\
\text { 1998). }\end{array}$ \\
\hline Roots &
\end{tabular}

Table 2. Popular names of Acanthospermum hispidum.

\begin{tabular}{|c|c|}
\hline Popular Names & References \\
\hline $\begin{array}{l}\text { Brazil } \\
\text { Amor-de-negro, Benzinho (Southeast), Cabeça-de-boi, Camboeiro, Carrapicho-de-carneiro, } \\
\text { Carrapicho-rasteiro (Northeastern), Chifre-de-carneiro, Chifre-de-veado (South), } \\
\text { Comboeiro, Delegado, Espinho-de-agulha, Espinho-de-carneiro, Espinho-de-cigano, } \\
\text { Federação (Northeastern), Maroto (Southeast), Picão-da-praia, Poejo-da-praia, Retirante } \\
\text { (Northeastern). }\end{array}$ & $\begin{array}{l}\text { Bahia, 1979; Bacchio \& Leitão } \\
\text { Filho, 1972; Braga, 1976; } \\
\text { Coimbra, 1994; Brandão et al., } \\
\text { 1986a; Corrêa, 1978; Diniz, 1998; } \\
\text { Lorenzi, 1982; Matos, 1997; } \\
\text { Morais, 2005; USDA, 2004. }\end{array}$ \\
\hline $\begin{array}{l}\text { English Language } \\
\text { Bristly-Starbur, Goat's-head, Herbe-tricorne (Mauritius); Star-burr Slingshot, Texas- } \\
\text { cockspur, Upright-starbur (USA). }\end{array}$ & $\begin{array}{l}\text { Natural Resources Conservation } \\
\text { Service, 2005; USDA, } 2004 .\end{array}$ \\
\hline $\begin{array}{l}\text { Spanish } \\
\text { Cacharro; Carrapichino (Colombia); Carrapicho rasteiro (Colômbia); Cuajrilla (Argentina), } \\
\text { Chinna-Palleru; Corona-de-la-reina (Spain); Cuagrilla; Cujarilla (Argentina); Espinoso } \\
\text { (Bolivia); Espuela-de-Caballero; Estrella (Bolivia); Gandhichedi; Gokhura; Guagrilla } \\
\text { (Argentina); Gurkul-Kanta; Hurab-Elhowsa; Mala-mujer (Dominique Republic); Ovesha } \\
\text { Ca-a; Pecado-Mortal; Sraha-Nsoe; Tacuc (Bolívia); Toro-rati (Paraguay); Torito } \\
\text { (Argentina); Toro rati (Paraguay); Yerba-del-Pecado-Mortal. }\end{array}$ & $\begin{array}{llr}\text { Corrêa, } & 1926 ; & \text { HortiPlex } \\
\text { Database, } & \text { 2005; } & \text { Natural } \\
\text { Resources } & \text { Conservation } & \text { Service, } \\
\text { 2005; } & \text { MS Swaminatham } \\
\text { Research } \quad \text { Foundation, 2005; } & \\
\text { USDA, 2004. }\end{array}$ \\
\hline $\begin{array}{l}\text { Africa } \\
\text { Jina ia kawaida; Kasinyawa (Nigeria); Dágunró (Jêje-Nagô). }\end{array}$ & USDA, 2004. \\
\hline $\begin{array}{l}\text { Others Languages } \\
\text { Kaandhi-thala (Malasya); Kattu nerinji, Saroto (India). }\end{array}$ & USDA, 2004. \\
\hline
\end{tabular}

The initial steps of an ethnological study usually focus on the synonymy of popular names (which can vary greatly depending on the region, as was observed in the present study), use, indications, appearance, etc. This information is presented in Table 2, together with bibliographic references and, when possible, the region or country of origin.

In addition to the many medical indications found for $A$. hispidum there are also variations on the plant part utilized. In India the seeds are ingested orally to treat bed wetting, while in Malaysia, the entire plant is mixed with castor oil and applied to the skin to treat scabies. Corrêa (1926) compiled a basic compendium of medicinal plants in Brazil, and described the use from the roots of A. hispidum to treat coughs and bronchitis, while noting that the seeds are toxic to chickens. Other authors have indicated the use of this plant for treating bronchial spasms (Braga, 1976; Lorenzi, 1982; Silva \& Oliveira, 1994; Matos, 1997).

Although recognizing that the two species are distinct, Lorenzi \& Matos (2002) attributed the same properties and the same popular names to both A. hispidum and A. australe. Barros \& Napoleão (2003) also noted that these species were used in Afro-Brazilian religious ceremonies (candomblé). A collection of the indications encountered for $A$. hispidum are is listed in Table 3.

\section{Pharmacology}


Table 3. Ethnopharmacological information concerning Acanthospermum hispidum.

\begin{tabular}{|c|c|}
\hline Uses & References \\
\hline \multicolumn{2}{|l|}{ Part of the plant not mentioned } \\
\hline $\begin{array}{l}\text { Antipyretic; allergic bronchitis; sudorific, depurative; adstringent; infectious } \\
\text { diseases, anthelmintic, antalgic, abortifacient, to treat boils, and hypertension. }\end{array}$ & $\begin{array}{l}\text { Braga, 1976; Lorenzi, 1982; Del Vitto et al., } \\
\text { 1997; Menut et al., 1995, Fleischer et al., } 2003 .\end{array}$ \\
\hline \multicolumn{2}{|l|}{ Entire plant } \\
\hline Contraceptive, antipyretic, to cough and bronchitis, abortive, toxic for animals. & $\begin{array}{l}\text { Martinez-Courvetto, 1981; Matos, 1997; } \\
\text { Lemonica \& Alvarenga, 1994; Adam, } 1978 .\end{array}$ \\
\hline \multicolumn{2}{|l|}{ Aerial parts } \\
\hline Diuretic, febrifuge, urinary diseases, gonorrhea. & Coimbra, 1994; Hussain et al., 1990. \\
\hline \multicolumn{2}{|l|}{ Leaves } \\
\hline $\begin{array}{l}\text { Dysmenorrhea, gonorrhea, dysentery, hematury, antipyretic, Candomblé } \\
\text { religious. }\end{array}$ & $\begin{array}{l}\text { Garcia-Barriga, 1975; Caceres et al., 1995; } \\
\text { Novy, 1997; Reddy et al., 1989; Ramachandra } \\
\text { \& Nair, 1981; Barros \& Napoleão, } 2003 \text {. }\end{array}$ \\
\hline \multicolumn{2}{|r|}{ 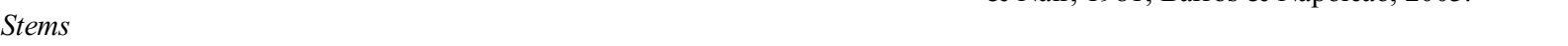 } \\
\hline Dysentery & Novy, 1997. \\
\hline \multicolumn{2}{|l|}{ Roots } \\
\hline Dysentery, expectorant, to cough and bronchitis, allergic bronchitis. & $\begin{array}{l}\text { Novy, 1997; Lorenzi, 1982; Silva \& Oliveira, } \\
\text { 1994; Diniz et al., } 1997 .\end{array}$ \\
\hline
\end{tabular}

Table 4 lists information relevant to the biological activity of $A$. hispidum as described in the literature.

Preliminary studies indicated that $A$. hispidum showed low toxicity (Araújo et al., 1989), information that was confirmed in later publications in which root extracts of this species were found to have neither bactericidal or mutagenic effects, nor did they show toxicity at doses up to $2 \mathrm{~g} / \mathrm{kg}$ in rats (Hussain et al., 1990). Studies by Bakhita \& Adam (1978a,b), however, had showed the toxicity of ingested seeds in mice as a result of liver damage, glomerular atrophy, congestion and hemorrhaging in the spleen, the lungs and the heart, in addition to catarrhal enteritis (Bakhita \& Adam, 1978a,b), as noted in Table 5. The observed toxicity of the seeds resulted in the classification of this plant as "restricted" by the Food and Drugs Administration - FDA (USA) (FDA 2005).

Due to its common occurrence, Acanthospermum hispidum is easy to identify and viable for cultivation.

The phytochemical profiles of cultivated plants did not show significant differences from those of spontaneous individuals, nor did this profile alter during growth and development, thus making it apt for harvesting after only short periods of growth.

In general, few biological or phytochemical studies have focused on the roots of Acanthospermum hispidum although they are extensively used in popular medicine throughout northeastern Brazil (although not commonly in other localities), pointing to the need for more research concerning this plant part.

On the other hand, tests of acute, sub-acute and chronic toxicity, together with pre-clinical trials of possible anti-asthmatic action, support the widespread and popular use of "Espinho-de-cigano". Better defined indications, contraindications and doses, as well as standardization of the raw material used in medicinal preparations and formulations would allow the product to advance more rapidly to the phase of clinical trials.

To that end, it will be important to gather more technical information concerning products derived from "Espinho-de-cigano" that will meet the standards of the National Health Service Agency (Anvisa). This type of information is available for only a very few native Brazilian species, neglecting many with well-established and traditional folk uses.

While large pharmaceutical industries tend to focus on research on "new" compounds with therapeutic potentials that can bring in short- to medium-term profits, in order to attend the necessities of developing countries where there are only limited public resources available for research, and the populations are more susceptible to illnesses and all of their consequences, it might be more efficient to restrict initial research to proving the efficiency of established folk remedies and to standardizing the quality and safety of plant extracts already widely used and approved by local populations.

\section{CONCLUSION}

This specie is easily identified and its occurrence is wide during the rainy periods, viable to domestic cultivation, without alterations in the phytochemical standard. This literature review evidenced the scarcity of studies about the roots; the sesquiterpene lactones in this organ showed be promissory as phytochemical markers to the quality control for the phytotherapics. In spite of the toxicity founded in seeds, the roots showed $\mathrm{LD}_{50}$ i.p. $=$ $2 \mathrm{~g} . \mathrm{kg}^{-1}$ body weight, indicating safety to its use. The need of establishment of a dossier from the product, attending the exigencies of the current legislation, is evident and urgent, in consequence of the extensive commerce of different products for long years. 
Table 4. Biological activity of Acanthospermum hispidum.

\begin{tabular}{|c|c|}
\hline Activities & References \\
\hline \multicolumn{2}{|l|}{ Part of the plant not described } \\
\hline Anti-cancer activity in vivo & Jakupovic et al., 1986. \\
\hline Increase of cardiac frequency; Increase of coronary rate, & Medeiros et al., 1988. \\
\hline Increase of blood pressure & Brandão et al., 1988. \\
\hline $\begin{array}{l}\text { Inhibitors histamine induced contraction }(80 \%) \text { in guinea pig isolated ileum. Inhibitors ocitocine } \\
\text { induced contraction }(100 \%) \text { and bradicinine }(69 \%) \text { in rats' uterus isolated. Inhibitors isolated } \\
\text { trachea contraction in guinea pig in compare to isoprenaline }\end{array}$ & \\
\hline Bactericide, fungicide and antifeedant & Kraus et al., 1994. \\
\hline \multicolumn{2}{|l|}{ Aerial Part } \\
\hline Sweetener & Hussain et al., 1990. \\
\hline Acanthospermolide presented anti-cancer activity in vitro and in vivo & Fleischer et al., 2003; Sanon et \\
\hline Consistent antimalaria activity (leaves + stems) & al., 2003. \\
\hline $\begin{array}{l}\text { Leaves and flowers present antimicrobial activity against Streptococcus pyogennes, } \\
\text { Staphylococcus aureus. Bacillus subtilis, Salmonella typhi and Clostridium histolyticum, } \\
\text { Microsporum gypseum, Cladosporides cladosporioides, Trichophyton mentagrophytes }\end{array}$ & Portillo et al., 2001. \\
\hline Resistance enhanced by splenic hematopoiesis & Pereira, 2001. \\
\hline \multicolumn{2}{|l|}{ Entire plant } \\
\hline Inactive against Leishmania braziliensis, L. donovani, L. amazonensis and Trypanosoma cruzi & Fournet et al., 1994. \\
\hline \multicolumn{2}{|l|}{ Leaves } \\
\hline Antimalaric Activity (Biomphalaria glabrata) & Silva et al., 1996. \\
\hline Active against Neisseria gonorrhea & Caceres et al., 1995. \\
\hline Active against Virus-Pseudorabies & Summerfield et al., 1997. \\
\hline $\begin{array}{l}\text { Moderated IgG increase production and stimulation of interleukin- } 2 \text { and } 4 \text {; leukocytes } \\
\text { proliferation increase; no monocytes activate; }\end{array}$ & Summerfield et al., 1998. \\
\hline $\begin{array}{l}\text { Inactive for Bacillus subtilis, Staphylococcus aureus, Streptococcus pyogenes, Salmonella typhi } \\
\text { and Clostridium histolyticum }\end{array}$ & $\begin{array}{l}\text { Fleischer et al., 2003; Menut et } \\
\text { al., } 1995 .\end{array}$ \\
\hline $\begin{array}{l}\text { Have not present activity against the following microorganism: Bacillus subtilis, Escherichia } \\
\text { coli, Klebsiella pneumoniae, Pseudomonas aeruginosa, Salmonella typhimurium, and } \\
\text { Staphylococcus aureus, Streptococcus faecalis, Mycobacterium phlei, Virus-Herpes simplex, } \\
\text { Poliovirus I, Sindbis, Candida albicans and Plasmodium falciparum }\end{array}$ & El Tahir et al., 1999. \\
\hline \multicolumn{2}{|l|}{ Roots } \\
\hline $\begin{array}{l}\text { Presented good activity against Sthaphylococcus aureus, moderated activity against Salmonella } \\
\text { and E. coli }\end{array}$ & Araújo et al., 1989. \\
\hline $\begin{array}{l}\text { i.v.- carrageenin rat paw edema inhibitors was not evidenced hypotension, effect no-blocked by } \\
\text { atropine or propanolol }\end{array}$ & Caetano et al., 1990. \\
\hline
\end{tabular}

Table 5. Pre-clinical toxicology of Acanthospermum hispidum.

\begin{tabular}{|c|c|}
\hline Disturbances & References \\
\hline \multicolumn{2}{|l|}{ Part of the plant not described } \\
\hline $\begin{array}{l}\text { Citotoxic activity; } 1-2 \mathrm{~g}_{\mathrm{kg}}{ }^{-1} \text { body weight in which did not present acute toxicity as well as } \\
\text { muthagenic effect }\end{array}$ & $\begin{array}{l}\text { Jakupovic et al., 1986; Hussain } \\
\text { et al., } 1990 .\end{array}$ \\
\hline \multicolumn{2}{|l|}{ Aerial parts } \\
\hline Abortion was evidenced in the organogenic period, but may block the implantation & Lemonica et al., 1994. \\
\hline Ictiotoxic activity was negative & Dutra et al., 1996. \\
\hline \multicolumn{2}{|l|}{ Seeds } \\
\hline Hemorrhage, weakness and diarrhea. external bad formation, abortion and visceral anomalies & Di Stasi et al., 1989. \\
\hline \\
\hline $\begin{array}{l}\text { Alterations of hairs, reduced appetite, respiration enhanced, ascites, visceral hemorrhage, } \\
\text { depression and dispnoea and death }\end{array}$ & Bakhita \& Adam, 1978 a and b. \\
\hline \multicolumn{2}{|l|}{ Entire Plant } \\
\hline Citotoxity & Bhakuni et al, 1971. \\
\hline \multicolumn{2}{|l|}{ Roots } \\
\hline $\mathrm{LD}_{50}$ i.p. $=2 \mathrm{~g} \cdot \mathrm{kg}^{-1}$ body weight & Araújo et al., 1989. \\
\hline
\end{tabular}




\section{REFERENCES}

Adam SEI 1978. Toxicity of indigenous plants and agricultural chemical in farm animals. J Clin Toxicol 13: 269-280.

Agra MF, França PF, Barbosa-Filho JM 2007. Synopsis of the plants known as medicinal and poisonous in Northeast of Brazil. Rev Bras Farmacogn 17: 114-140.

Agra MF, Silva KN, Basílio IJLD, França PF, Barbosa-Filho JM 2008. Survey of medicinal plants used in the region Northeast of Brazil. Rev Bras Farmacogn 18: 472508.

Anvisa 2000. Agência Nacional de Vigilância Sanitária. Registro de Medicamento Fitoterápico Novo. Resolução: RDC $\mathrm{N}^{\circ} 17$ ANVS/MS, de 24 de fevereiro de 2000. D.O.U. de $25 / 02 / 2000$.

Aranha C, Bacchio O, Leitão Filho HF 1972. Plantas Invasoras de Culturas. São Paulo: HUCITEC/Min. da Agricultura/Agiplan - BID, v. 2.

Araújo EL, Pisciottano MNC, Maia MB, Afiatpour P, Souza MA, Rego ML, Wanderley MMC, Silva NH 1989. Avaliação fitoquímica e farmacológica preliminar do Acanthospermum hispidum (Espinho de Cigano). Biologica Brasilica 1 (Supl.1): 181.

Araújo EL, Randau KP, Xavier HS 2002. Plantas medicinais em destaque: Acanthospermum hispidum DC (Asteraceae). Racine 66: 32-34.

Bahia 1979. Governo do Estado. Inventário de Plantas Medicinais do Estado da Bahia. Salvador: Governo do Estado/Sub-Secretaria de Ciência e Tecnologia.

Bakhita A, Adam SEI 1978a. Toxicity of Acanthospermum hispidum to mice. J Comp Path 88: 443-448.

Bakhita A, Adam SEI 1978b. Effects of Acanthospermum hispidum on goats. $J$ Comp Path 88: 533-544.

Barros JFP, Napoleão E 2003. Ewé òrisà: uso litúrgico e terapêutico dos vegetais nas casas de candomblé jêjenagô. Rio de Janeiro: Bertrand Brasil.

Barroso JG, Peixoto AL, Ichaso CL 1991. Sistemática de Angiospermas do Brasil. v.2. Viçosa: Imprensa Universitária da Universidade Federal de Viçosa, MG.

Bhakuni DS, Dhar ML, Dhar MM 1971. Screening of Indian plants for biological activity. Part III. Ind J Exp Biol 9: 91.

Bohlman F, Jakupovic J, Zdero C, King RM 1979. Neue melampolide und cis, cis-germacranolide aus vertretern der subtribus Melampodiinae. Phytochemistry 18: 625-630.

Braga R 1976. Plantas do Nordeste, Especialmente do Ceará. Natal: Editora UFRN.

Brandão M, Gavilanes ML, Laca-Buendia JP 1986a. Plantas daninhas ocorrentes na cultura de trigo (Triticum aestivum L) no Estado de Minas Gerais. XXXVII Congresso Nacional de Botânica. Minas Gerais, Brasil.

Brandão M, Guimarães EF, Mautoe L 1986b. Plantas consideradas daninhas ocorrentes na faixa litorânea do Município do Rio de Janeiro. XXXVII Congresso Nacional de Botânica. Minas Gerais, Brasil.

Brandão VJ, Agra MF, Brito ARMS 1988. Comparação de dois métodos de avaliação toxicológica de extratos hidroalcoólicos de plantas brasileiras. X Simpósio de Plantas Medicinais do Brasil, São Paulo, Brasil.

Bremer K 1994. Asteraceae: Cladistics and Classification. Portland: Timber Press.

Bruneton J 1991. Elementos de Fitoquímica y de Farmacognosia. Zaragosa/ES: Acribia.

Caceres A, Menedez H, Cohobon E 1995. Antiogonorrhoeal activity of plants used in Guatemala for the treatment of sexually transmitted diseases. $J$ Ethnopharmacol 48: $85-88$

Caetano NP, Maia B, Afiatpour P 1990. Avaliação fitoquímica, microbiológica e farmacológica preliminar do Acanthospermum hispidum (espinho de cigano).
XI Simpósio de Plantas Medicinais do Brasil, João Pessoa, Brasil.

Cartagena E, Bardon, A, Catgalan AN 2000. Germacranolides and a new type of guaianolide from Acanthospermum hispidum. J Nat Prod 63: 1323-1328.

Coimbra R 1994. Manual de Fitoterapia. Belém: CEJUP.

Corrêa MP 1926. Dicionário das Plantas Úteis do Brasil: Rio de Janeiro: Editora Nacional,

Corrêa MP 1978. Dicionário das Plantas Úteis do Brasil. v.6. Rio de Janeiro: Editora Nacional. Reimpressão MEC/ IBAMA.

Cronquist A 1981. An integral system of classification of flowering plants. New York: Columbia University Press.

Cunha AG 1982. Dicionário Etimológico Nova Fronteira da Lingua Portuguesa. Rio de Janeiro: Nova Fronteira.

Cunha LHS, Brandão M, Laca-Buendia JP, Gavilanes ML 1985. Plântulas, frutos, frutos/sementes e sementes de plantas daninhas em pastagens naturais de cerrado no Estado de Minas Gerais. XXXVI Congresso Brasileiro de Botânica. Curitiba, Brasil.

Del Vitto LA, Petenatti EM, Petenatti ME 1997. Recursos herbolarios de San Luis (República Argentina) Primera Parte: Plantas Nativas 1. Multequina 6: 49-66.

Di Stasi LC, Santos EMG, Santos CM, Hiruma CA 1989. Plantas Medicinais na Amazônia. São Paulo: Editora da Universidade Estadual Paulista.

Diniz MFFM, Oliveira RAG, Medeiros ACD 1997. Memento Fitoterápico: as plantas como alternativa terapêutica: conhecimentos populares e científicos. João Pessoa: Editora Universitária,

Diniz MFFM, Oliveira RAG, Medeiros ACD, Malta Jr A 1998. Memento Fitoterápico. João Pessoa, Paraíba: Editora da Universidade Federal da Paraíba.

Dutra EA, Martins LS, Pires SG 1996. Ictiotoxicidade de plantas medicinais da região Nordeste. XIV Simpósio de Plantas Medicinais do Brasil. Florianópolis, Brasil.

El Tahir A, Satti GMH, Khalid SA 1999. Antiplasmodial activity of selected Sudanese medicinal plants with emphasis on Acacia nilotica. Phytother Res 13: 474-478.

Evans WC 1996. Trease and Evans' Pharmacognosy. London: Saunders.

FDA 2005. Foods \& Drugs Administration (USA). http:// www.cfsan.fda.gov/ djw/plantox.html. Accessed in 06/20/2005.

Fleischer TC, Ameade EPK, Sawer IK 2003. Antimicrobial activity of the leaves and flowering tops of Acanthospermum hispidum. Fitoterapia 74: 130-132.

Fournet A, Barrios AA, Munoz V 1994. Leishmanicidal and trypanocidal activities of Bolivian medicinal plants. $J$ Ethnopharmacol 41: 19-37.

Garcia QS 1992. Dormência e germinação em aquênio de Acanthospermum hispidum. Campinas, 100p. Dissertação de Mestrado em Biologia Vegetal na Universidade Estadual de Campinas, SP.

Garcia-Barriga H 1975. Flora Medicinal de Colombia. v. 2/3. Bogotá: Universidad Nacional de Bogotá.

Herz W, Kalyanarama PS 1975. Acanthospermal A and acanthospermal B, two new melampolides from Acanthospermum hispidum species. J Org Chem 40: 3486-3491.

HortiPlex Database 2005. www.hortiplex.com. Accessed in 06/27/2005.

Hussain RA, Lin Y-M, Poveda LJ 1990. Planta-derived sweetening agents: Saccharide and polyol constituents of some sweet-tasting plants. J Ethnopharmacol 28: 103-115.

ICBN 2005. International Code of Botanical Nomenclature. http://www.bgbm.fu-berlin.de/iapt/nomenclature/ code, accessed in 05/25/2005.

Jakupovic J, Baruah RN, Bohlmann F 1986. Further acanthispermolides from Acanthospermum hispidum. Planta Med 2: 154-155. 
Joly AB 1978. Botânica: Introdução à taxonomia vegetal. São Paulo: Editora Nacional.

Kraus W, Koll-Weber M, Maile R 1994. Biologically active constituents of tropical and subtropical plants. Pure Appl Chem 66: 2347-2352.

Lemonica IP, Alvarenga CMD 1994. Abortive and teratogenic effect of Acanthospermum hispidum DC and Cajanus cajan (L) Millps in pregnant rats. J Ethnopharmacol 43: $39-44$.

Lorenzi H 1982. Plantas Daninhas do Brasil. Nova Odessa/SP: Instituto Plantarum.

Lorenzi H, Matos FJA 2002. Plantas medicinais no Brasil: nativas e exóticas. Nova Odessa, SP: Instituto Plantarum.

Luo X-Y, Matsuomoto H 2002. Susceptibility of a broadleaved weed, Acanthospermum hispidum to the grass herbicide fluazifop-butyl. Weed Biol Manag 2: 98103.

Martinez-Corveto R 1981. Fertility-regulating plants used in popular medicine in Northeastern Argentina. Parodiana 1: 97-117.

Mathur SB, Bejarane LB 1976. Isolation of triacontane, $N$-butil eicosante and $N$-heptacosanol from Acanthospermum hispidum. Phytochemistry 15: 2026.

Matos FJA 1997. O Formulário Fitoterápico do Professor Dias da Rocha. Fortaleza: Editora UFC.

Medeiros IA, Brandão VJ, Cortes SF 1988. Isolamento do(s) princípio(s) farmacologicamente ativo(s) de Acanthospermum hispidum (Asteraceae). X Simpósio de Plantas Medicinais do Brasil. São Paulo, Brasil.

Menut C, Molangui T, Lamaty G 1995. Aromatic plants of Tropical Central Africa. XXIV Volatile Constituents of Acanthospermum hispidum DC from the Congo. $J$ Essent Oil Res 7: 589-592.

Messias AS, Noronha CFA 1994. Avaliação do efeito do composto urbano sobre plantas medicinais cultivadas na Estação Experimental de Itapirema - IPA. XIII Simpósio de Plantas Medicinais do Brasil. Fortaleza, Brasil.

Miranda LFP 1996. Análise comparativa da composição química de Acanthospermum hispidum DC em suas diferentes fenofases. Salvador, 78p. Dissertação de Mestrado, Instituto de Biologia da Universidade Federal da Bahia.

Morais SM, Dantas JDP, Silva ARA, Magalhães EF 2005. Plantas medicinais usadas pelos índios Tapebas do Ceará. Rev Bras Farmacogn 15: 169-177.

MS Swaminathan Research Foundation 2006. Center on sustainable agriculture and rural development. http:// www.mssrf.org/. Accessed in 08/26/2006.

Nair AGR, Subramanian SS, Bohlmann F 1976. Naturally occurring terpene derivates. 79: A new diterpene galactoside from Acanthospermum hispidum. Phytochemistry 15: 1776-1778.

Nair AGR, Rao SA, Voirin B 1985. Polyphenolic compounds from leaves of Acanthospermum hispidum. Fitoterapia 56: $249-250$.

Natural Resources Conservation Service 2005 http://plants. usda.gov/cgi_bin/topics.cgi. Accessed in 09/03/2005.

Novy JW 1997. Medicinal plants of the Eastern Region of Madagascar. J Ethnopharmacol 55: 119-126.

Odebiyi OO, Sofowora EA 1978. Phytochemical screening of Nigerian medicinal plants II. Lloydia 41: 234-246.

Pereira ACN 2001. Efeitos do extrato hidroalcoólico de Acanthospermum hispidum sobre a resposta imunológica. Campinas, 67p. Dissertação de Mestrado em Ciências Médicas, Universidade Estadual de Campinas, SP.

Portillo A, Vila R, Freixa B 2001. Antifungal activity of Paraguayan plants used in traditional medicine. $J$ Ethnopharmacol 76: 93-98

Ramachandram NAG, Subramana SS, Bohlmann F 1976. A new diterpene galactoside from Acanthospermum hispidum. Phytochemistry 15: 1776-1778.

Ramachandram VS, Nair NC 1981. Ethnobotanical observations on irulars of Tamil Nadu (India). J Econ Tax Bot 2: 183-190.

Ramachandram NAG, Rao SA, Voirin B 1985. Polyphenolic compounds from leaves of Acanthospermum hispidum. Fitoterapia 56: 249-251.

Reddy DB 1965. Control of Acanthospermum hispidum with weedicides. Plant Prot Bull 13: 67-68.

Reddy MB, Reddy KR, Reddy MN 1989. A survey of plant crude drugs of Anantapur District, Andhra Pradesh, Índia. Int J Crude Drug Res 27: 145-155.

Robbers JE, Speedie MK, Tyler VE 1997. Farmacognosia e Farmacobiotecnologia. São Paulo: Editorial Premier.

Sanon S, Ollivier E, Azas N 2003. Ethnobotanical survey and in vitro antiplasmodial activity of plants used in traditional medicine in Burkina Faso. J Ethnopharmacol 86: 143147.

Saraiva FRS 2000. Dicionário Latino-Português. Rio de Janeiro/Belo Horizonte: Livraria Garmer.

Schwerzel PJ, Thomas PEL 1979. Effect of cultivation frequency on the survival of seeds of six weeds commonly found in Zimbabwe Rhodesia. Rhod Agric J Zimb 5: 195199.

Seaman FC, Fischer NH, Stuessy TF 1980. Systematic implications of sesquiterpene lactones in the subtribe Melampodiinae. Biochem Syst Ecol 8: 263-271.

Silva MSH, Oliveira RAG 1994. Plantas Medicinais na Atenção Primária à Saúde. João Pessoa: Editora UFPB.

Silva SEM, Almeida DK, Paulo MQ 1996. Estudo Químico, Antimicrobiano e Toxicológico de Acanthospermum hispidum DC. XIV Simpósio de Plantas Medicinais do Brasil, Florianópolis, Brasil.

Sultanbawa MUS, Wannigama GP, Bandaranayake WM 1978. Chemical investigation of Ceylonese plants. Part XXIX. A survey of plants of Sri Lanka (Ceylon) for alkaloids I. Lloydia 41: 597-633.

Summerfield A, Keil GM, Mettenleiter TC 1997. Antiviral activity of an extract from leaves of the tropical plant Acanthospermum hispidum. Antiviral Res 36: 55-62.

Summerfield A, Saalmullera A 1998. Interleukin-2 dependent selective activation of porcine $\gamma-\delta$ T lymphocites by an extract from the leaves of Acanthospermum hispidum. Int J Immunopharmacol 20: 85-98.

Tabarelli M, Silva JMC (Org.) 2002. Diagnóstico da Biodiversidade de Pernambuco. v 1. Recife, Brasil: Massangana/Secretaria de Ciência, Tecnologia \& Meio Ambiente.

Tôrres AR, Oliveira RAG, Diniz MFFM, Araújo EC 2005. Estudo sobre o uso de plantas medicinais em crianças hospitalizadas da cidade de João Pessoa: riscos e benefícios. Rev Bras Farmacogn 15: 373-380.

USDA 2004 United States Department of Agriculture http:// www.usda.gov/wps/portal/usdahome. Accessed in 08/04/2004.

Verdi LG, Brighenete IMC, Pizzolatti MG 2005. Gênero Baccharis (Asteraceae): Aspectos químicos, econômicos e biológicos. Quim Nova 28: 85-94.

Voll E, Gazziero DLP, Karam D 1997. Dinâmica de populações de carrapicho-de-carneiro (Acanthospermum hispidum DC) sob manejo de solo e de herbicidas. Pesq Agr Bras 32: 897-904

Xavier HS, Araújo EL 1998. Avaliação cromatográfica de amostras de extratos fluidos de Acanthospermum hispidum DC (Asteraceae) cultivado e de ocorrência espontânea. $X V$ Simpósio de Plantas Medicinais do Brasil. Florianópolis, Brasil. 